\title{
Tick-Borne Encephalitis in Sheep, Romania
}

\section{Jiri Salat, Andrei D. Mihalca, Marian Mihaiu, David Modrý, Daniel Ruzek}

Little is known about the occurrence of tick-borne encephalitis in Romania. Sheep are an infection source for humans and are useful sentinels for risk analysis. We demonstrate high antibody prevalence $(15.02 \%)$ among sheep used as sentinels for this disease in $80 \%$ of the tested localities in 5 counties of northwestern Romania.

$\mathrm{T}$ ick-borne encephalitis (TBE) virus (family Flaviviridae, genus Flavivirus), is a zoonotic pathogen that causes severe neurologic disease in humans. In Europe, most cases of TBE are reported in Scandinavia and in countries in Central and Eastern Europe countries, but little is known about the current TBE epidemiologic situation in Romania.

The main tick vector for TBE virus, Ixodes ricinus, prefers leaf litter and the lower vegetation layers of temperate deciduous and mixed forests. In areas with high rainfall, I. ricinus ticks also occur in high densities in coniferous forests and in open areas such as grasslands (1). I. ricinus ticks are widely distributed in Romania (2) and are the most common ticks found on a variety of vertebrate hosts, including humans $(3,4)$.

Large domestic animals such as goats, sheep, and cattle are potential hosts for I. ricinus ticks. These animals may also develop an antibody response after infection with TBE virus without showing clinical signs and thus are a source of TBE virus among humans who consume nonpasteurized milk and milk products, which makes them valuable sentinels for the identification of TBE risk areas (5).

Romania has the third largest sheep flock in the European Union (EU), after Great Britain and Spain, totaling $\approx 9.5$ million sheep, which accounts for $11 \%$ of the total EU flock. Most of the animals are used for milk and meat production. The purpose of this study was to determine the current TBE virus infection status in northwestern Romania by using sheep as sentinels for TBE virus circulation.

Author affiliations: Veterinary Research Institute, Brno, Czech Republic (J. Salat, D. Ruzek); University of Agricultural Sciences and Veterinary Medicine, Cluj-Napoca, Romania (A.D. Mihalca, M. Mihaiu); Faculty of Veterinary Medicine and CEITEC VFU, University of Veterinary and Pharmaceutical Sciences, Brno (D. Modrý); Institute of Parasitology, Biology Centre of the Czech Academy of Sciences, Ceske Budejovice, Czech Republic (D. Ruzek)

DOI: https://doi.org/10.3201/eid2312.170166

\section{The Study}

In September 2016, we randomly selected 519 serum aliquots from adult sheep from samples previously collected (July-August 2016) by the National Program for Surveillance, Prevention, Control and Eradication of Animal Diseases in 5 counties in northwestern Romania (Figure). The counties, number of samples, and number of sampling sites were Bihor, 119 samples, 12 locations; Bistrița-Năsăud, 100 samples, 10 locations; Cluj, 100 samples, 7 locations; Mureș, 100 samples, 11 locations; and Sălaj, 100 samples, 10 locations). We froze the aliquots at $-20^{\circ} \mathrm{C}$ before processing. We used the IMMUNOZYM FSME (TBE) IgG All-Species kit (Progen GmbH, Heidelberg, Germany) ELISA to detect TBE virus antibodies. We retested samples exhibiting $\geq 25$ Vienna units/mL by using virus neutralization test (VNT) as described previously (6).

We tested samples from $168(32.37 \%)$ sheep with borderline or positive results from ELISA by using VNT, and this method identified $78(15.02 \%)$ animals as positive for antibodies specifically neutralizing TBE virus (online Technical Appendix Table, http://wwwnc.cdc.gov/EID/ article/23/12/17-0166-Techapp1.pdf). Positive results were distributed among the counties we investigated: the highest seroprevalence was identified in sheep in Bihor County $(27.73 \%)$ and the lowest seroprevalence in Mureș County (2\%) (Table; Figure). We found positive sheep samples in $40(80 \%)$ of 50 examined locations.

\section{Conclusions}

TBE has been reported previously in Romania, but few studies confirmed the presence of the virus (7-10). However, in the past 3 decades, except for a few occasional records (11) and small-scale serologic surveys during clinical outbreaks, there have been large knowledge gaps in the studies on TBE in Romania, and the prevalence and distribution remain fairly unknown. We used sheep as sentinels for TBE virus distribution in northwestern Romania and identified the virus by VNT in $15.02 \%$ of sheep in 40 of 50 examined localities in 5 counties.

According to the latest technical report by the European Centre for Disease Control and Prevention (12), during 2008-2010, only 14 cases of TBE were reported among humans in Romania. All 14 cases originated in 5 counties in northwestern Romania; incidence was low $(<0.5 / 100,000$ inhabitants $)$ in Bihor, Bistrița-Năsăud, Cluj, and Mureș and moderate $(0.5-4.0 / 100,000$ inhabitants) in Sălaj. In a recent survey done by collecting $I$. ricinus ticks from vegetation, livestock, and reptiles in central 


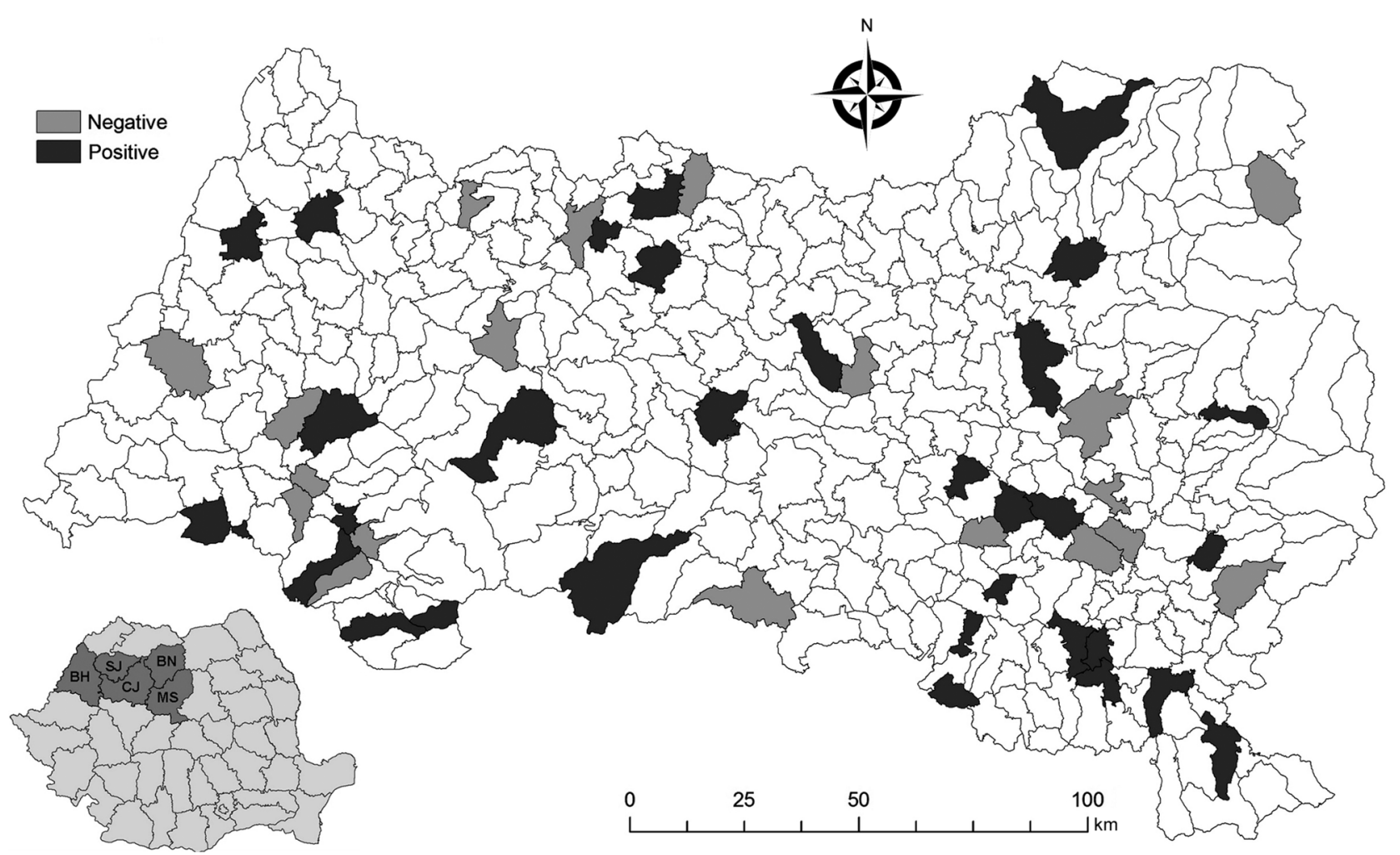

Figure. Locations in northwestern Romania where sheep were positive for tick-borne encephalitis virus-specific antibodies, determined by using virus neutralization test (6). BH, Bihor; BN, Bistriţa-Năsăud; CJ, Cluj; MS, Mureş; SJ, Sălaj.

and southeastern Romania, the prevalence of the TBE virus estimated by using molecular methods was $<1 \%$ (13). Coipan et al. evaluated the seropositivity for TBE in 51 patients who had neurologic signs and were admitted to a hospital in Sibiu County, Romania; specific TBE antibodies were found in samples from $38(75 \%)$ patients (14). An outbreak of rural TBE was reported in the central Romania region of Transylvania, related to consumption of infected goat milk; specific serology in $41.5 \%$ of the patients was positive for TBE virus (15). Similar seroprevalence studies in other outbreaks found lower seropositivity values $(5.8 \%-11.6 \%)$ in human patients $(15)$; the same study randomly evaluated 1,669 human serum samples from Transylvania and reported a $0.5 \%$ seroprevalence for TBE. Taken together, these results suggest that clinical cases of TBE in Romania are largely underreported, and many case-patients are misdiagnosed.

Our study confirms that TBE virus is endemic in northwestern Romania and should be considered a public health risk in this country. Considering the number of sheep and their almost ubiquitous presence in this country, their sentinel role in countrywide mapping of the TBE distribution should be evaluated.

This study was partially supported by the Czech Science Foundation (project No. 16-20054S) and by project LO1218 with financial support from the Ministry of Education, Youth and Sports of the Czech Republic under the NPU I program. J.S. was supported by project QJ1510104 of the Ministry of Agriculture of the Czech Republic. The work has been done under the frame of COST Action TD1303 "EurNegVec."

\begin{tabular}{lccccc}
\hline \multicolumn{7}{l}{ Table. Seroprevalence of tick-borne encephalitis in sheep, northwestern Romania* } & & \\
\hline County & No. samples & No. locations & $\begin{array}{c}\text { ELISA-positive samples, } \\
\% \dagger\end{array}$ & $\begin{array}{c}\text { VNT-positive samples, } \\
\%\end{array}$ & $\begin{array}{c}\text { No. VNT-positive } \\
\text { locations }\end{array}$ \\
\hline Bihor & 119 & 12 & 29.41 & 27.73 & 11 \\
Bistrița-Năsăud & 100 & 10 & 18.00 & 12.00 & 1.00 \\
Cluj & 100 & 7 & 67.00 & 2.00 & 5 \\
Mureș & 100 & 11 & 16.00 & 20.00 & 2 \\
Sălaj & 100 & 10 & 32.00 & 15.2 & 3 \\
Total & 519 & 50 & 32.37 & & 32 \\
\hline
\end{tabular}

*Testing locations were within communes subdivision of counties in Romania.

†Includes all positive and suggestive samples with antibody titer $\geq 25$ Vienna units $/ \mathrm{mL}$. 
Dr. Salat is a research scientist at the Veterinary Research Institute, Brno, Czech Republic. His research interests include tick-borne encephalitis and other zoonotic viral diseases.

\section{References}

1. Gray JS, Kahl O, Robertson JN, Daniel M, Estrada-Peña A, Gettinby G, et al. Lyme borreliosis habitat assessment. Zentralbl Bakteriol. 1998;287:211-28. http://dx.doi.org/10.1016/ S0934-8840(98)80123-0

2. Mihalca AD, Gherman CM, Magdaş $\mathrm{C}$, Dumitrache MO, Györke A, Sándor AD, et al. Ixodes ricinus is the dominant questing tick in forest habitats in Romania: the results from a countrywide dragging campaign. Exp Appl Acarol. 2012;58:17582. http://dx.doi.org/10.1007/s10493-012-9568-3

3. Mihalca AD, Dumitrache MO, Magdaş C, Gherman CM, Domşa C, Mircean V, et al. Synopsis of the hard ticks (Acari: Ixodidae) of Romania with update on host associations and geographical distribution. Exp Appl Acarol. 2012;58:183-206. http://dx.doi.org/ 10.1007/s10493-012-9566-5

4. Briciu VT, Titilincu A, Tăţulescu DF, Cârstina D, Lefkaditis M, Mihalca AD. First survey on hard ticks (Ixodidae) collected from humans in Romania: possible risks for tick-borne diseases. Exp Appl Acarol. 2011;54:199-204. http://dx.doi.org/10.1007/ s10493-010-9418-0

5. Klaus C, Beer M, Saier R, Schau U, Moog U, Hoffmann B, et al. Goats and sheep as sentinels for tick-borne encephalitis (TBE) virus - epidemiological studies in areas endemic and non-endemic for TBE virus in Germany. Ticks Tick Borne Dis. 2012;3:27-37. http://dx.doi.org/10.1016/j.ttbdis.2011.09.011

6. Širmarová J, Tichá L, Golovchenko M, Salát J, Grubhoffer L, Rudenko N, et al. Seroprevalence of Borrelia burgdorferi sensu lato and tick-borne encephalitis virus in zoo animal species in the Czech Republic. Ticks Tick Borne Dis. 2014;5:523-7.

http://dx.doi.org/10.1016/j.ttbdis.2014.03.008

7. Drăgănescu N. Study of some current viral encephalitides in the Socialist Republic of Rumania [in Rumanian]. Stud Cercet Inframicrobiol. 1968;19:297-312.

8. Drăgănescu N, Gîrjabu E, Iftimovici R, Totescu E, Iacobescu V, Tudor G, et al. Investigations on the presence of antibodies to alphaviruses, flaviviruses, Bunyavirus and Kemerovo virus in humans and some domestic animals. Virologie. 1978;29:107-11.

9. Drăgănescu N. Study of arboviruses in Romania (1958-1978). Results obtained in the "Stefan S. Nicolau" Institute of Virology. Virologie. 1979;30:283-93.

10. Ardeleanu D, Ardeleanu A, Albeanu M, Pricunda G, Drăgănescu N. Some epidemiological aspects of infections caused by tick-borne encephalitis virus in the region of Gorj [in Romanian]. Stud Cercet Inframicrobiol. 1968;19:87-90.

11. Petrescu A, Copelovici Y, Drăgănescu N, Bîrnaure F, Gîrjabu E, Mihail A, et al. The evidence of circulation of some viruses in a great town of Romania during the first half of 1992. Rev Roum Virol. 1993;44:243-51.

12. European Centre for Disease Prevention and Control. Epidemiological situation of tick-borne encephalitis in the European Union and European Free Trade Association countries. Stockholm: The Centre; 2012 [cited 2017 Aug 31]. https://ecdc.europa.eu/en/publications-data/epidemiologicalsituation-tick-borne-encephalitis-european-union-and-european

13. Vladimirescu A, Dumitrescu G, Ionescu L, Necsulescu M, Moraru V, Popescu D, et al. Real-Time PCR studies regarding the Borrelia burgdorferi, Francisella tularensis, tick borne encephalitis virus (TBEv) and Crimeean Congo hemorrhagic fever virus (CCHFv) occurrence in the Romanian ticks. Int J Infect Dis. 2016;45S:193-4. http://dx.doi.org/10.1016/j.ijid.2016.02.448

14. Coipan EC, Alexse A, Vladimirescu AF, Nicolescu G. Seropositivity among human subjects for both TBEV and Borrelia burgdorferi s.l. during a TBE outbreak in Sibiu County, Romania. Int J Infect Dis. 2008;12(S1):e334. http://dx.doi.org/10.1016/ j.ijid.2008.05.892

15. Molnár GB, Persecă T, Feder A, Păcuraru D, Marialaki E, Cojan A. Epidemiological assessment of morbidity and natural foci of TBE-CEE virus infection in Transylvania [in Romanian]. Rev Med Chir Soc Med Nat Iasi. 2008;112:471-7.

Address for correspondence: Andrei D. Mihalca, Faculty of Veterinary Medicine, University of Agricultural Sciences and Veterinary Medicine, Calea Manastur 3-5, Cluj-Napoca 400372, Romania; email: amihalca@usamvcluj.ro

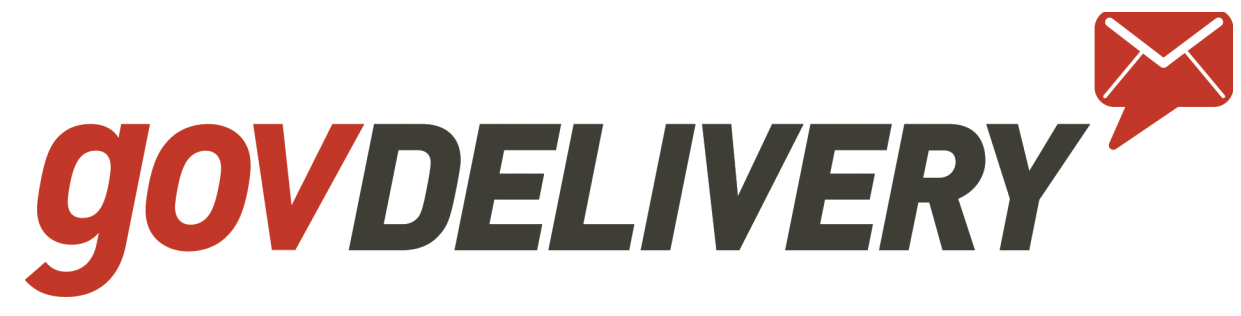

\title{
Manage your email alerts so you only receive content of interest to you.
}

\author{
Sign up for an online subscription: \\ wwwnc.cdc.gov/eid/subscribe.htm
}

